\title{
Manuscript Collections: The William L. Harding Collection Held by the State Archives of Iowa
}

\author{
EdWARD N. McConnell \\ JAMES J. JULICH
}

\begin{abstract}
The State Archives of Iowa is the main repository for governors' papers dating from the territorial period to the present; its holdings include the gubernatorial papers of William $L$. Harding. This collection, totaling thirty-seven cubic feet, spans the years 1917 to 1921 and constitutes part of the official records of the executive department of state. The Harding papers are divided into three main sections: General Correspondence, Council of Defense, and Criminal Records.

General Correspondence is composed of 440 folders and totals eleven cubic feet. The contents include correspondence, reports, applications, recommendations, appointments, etc., dealing with private citizens, state departments, boards and commissions, the state legislature, foreign consuls and representatives, the federal government, and other states.

The second main section, the largest part of the collection, is the Council of Defense files which contain 591 folders totaling nineteen cubic feet. The State Council of Defense of Iowa was created by Governor Harding in 1917 when the United States entered World War I. The five-member council appointed com-
\end{abstract}


mittees to oversee lowa's war effort. Some of the major committees were: Agriculture and Food, Military, Industrial Survey, and Women's Organizations. Affiliated county councils were created in each county.

The arrangement of this record series follows the committee and county structure. Some examples of records included are: appointments, reports of special agents, agricultural and industrial surveys, reaction to implementation of the foreign language proclamation, and other defense related activities on the state and local level. A large number of photographs (around one hundred) are included in this section. The major subjects depicted are Iowa's wartime industries and the national shipbuilding effort.

Criminal Records, the third main section, contains 222 folders totaling seven cubic feet. This includes official actions and transcripts in addition to correspondence concerning pardons, discharges, suspensions of sentences, etc. It is broken down by penal institution then alphabetically by specific prisoner. For county cases, the arrangement is by county. In addition to this seven cubic feet there are four cubic feet of extradition files covering the years 1912 to 1921 . These files include actions by administrations prior to Harding's.

The State Archives of Iowa, located on the fourth floor of the Records and Property Center, East 7th and Court Avenue, Des Moines, is open from 8 a.m. to 4 p.m. Monday through Friday. Researchers are welcome. 
Copyright of Annals of Iowa is the property of State of Iowa, by \& through the State Historical Society of Iowa and its content may not be copied or emailed to multiple sites or posted to a listserv without the copyright holder's express written permission. However, users may print, download, or email articles for individual use. 